\title{
EL AMIGO LIBERAL: REPRESENTACIONES DE LO JUDÍO Y DE LOS JUDÍOS EN TEXTOS DE BORGES
}

\author{
THE LIBERAL FRIEND, REPRESENTATIONS \\ OF JEWISHNESS AND JEWS IN BORGES' TEXTS \\ Diego E. Niemetz \\ Universidad Nacional de Cuyo. Mendoza, Argentina \\ diegoniemetz@gmail.com
}

\begin{abstract}
Resumen: El artículo se propone indagar acerca del modo en que el imaginario etnicista, en relación a las representaciones de lo judío, es incorporado y naturalizado en la obra de Jorge L. Borges, autor asociado con el ala liberal del campo literario argentino (sector que hizo suyas las banderas del cosmopolitismo y, particularmente, del filosemitismo). Específicamente estudiaremos cómo es tratado lo judío (personajes de ese origen o temas relacionados con ese grupo étnico), en textos producidos por Borges hacia 1949 y 1967 y apreciaremos de qué manera el ideario antisemita es reproducido por el escritor. A partir de los deslindes teóricos de Van Dijk y de Bourdieu en relación al pensamiento sustancialista, al sentido común y al racismo de la elite simbólica, deseamos indagar cómo ciertos estereotipos resultan cristalizados hasta tal punto en el ideario social, que se vuelven marcos de referencia incluso para autores que los rechazan abiertamente. En gran medida, este esfuerzo apunta a la necesidad de desnudar los mecanismos de naturalización de los que se valen los autores para incluir elaboraciones del sentido común que se materializan tanto a nivel narrativo como lingüístico.
\end{abstract}

Palabras clave: Literatura argentina, Jorge Luis Borges, sentido común y discurso ideológico, estereotipos étnicos, filosemitismo y antisemitismo.

\begin{abstract}
The following article intends to inquire about the way in which the ethinicist imaginary, in relation to representations of Jewishness, is incorporated and naturalized in the works of Jorge L. Borges, author associated with the liberal wing of the Argentinean literary field (which endorsed the flags of cosmopolitanism and, particularly, of philo-Semitism). Specifically, we will study how Jewishness is dealt with (characters from that origin or topics related to that ethnic group), in texts produced by Borges towards 1949 and 1967, and we will examine how the anti-Semitic ideology is reproduced by the writer. On the basis of the theoretical definitions of Van Dijk and Bordieu in relation to substantialist thinking, to common sense and to racism of the symbolic elite, we wish to investigate how certain stereotypes become crystallized to
\end{abstract}


such an extent in the social ideology, that they turn to be reference frameworks even for authors that openly reject them. To a large extent, this endeavor aims to the need to strip down the mechanisms of naturalization used by authors to include elaborations of common sense that are materialized both on narrative and linguistic levels.

Keywords: Argentinian literature, Jorge Luis Borges, common sense and ideological discourse, ethnic stereotypes, philo-Semitism and anti-Semitism.

Recibido: 15.03.2016. Aceptado: 20.07.2016.

- N un CÉlEBre PASAJE de "El Aleph", uno de los cuentos más divulgados de Jorge Luis Borges, puede leerse:

Arribo, ahora, al inefable centro de mi relato, empieza aquí, mi desesperación de escritor. Todo lenguaje es un alfabeto de símbolos cuyo ejercicio presupone un pasado que los interlocutores comparten; ¿cómo transmitir a los otros el infinito Aleph, que mi temerosa memoria apenas abarca? ${ }^{1}(624)$.

Después de enumerar una serie de imágenes con las cuales se intenta conceptualizar la inasible idea del Aleph, el escritor, en clave autoficcional y con un obvio componente irónico, remata el segmento del siguiente modo:

Quizá los dioses no me negarían el hallazgo de una imagen equivalente, pero este informe quedaría contaminado de literatura, de falsedad. Por lo demás, el problema central es irresoluble: la enumeración, si quiera parcial, de un conjunto infinito. En ese instante gigantesco, he visto millones de actos deleitables o atroces; ninguno me asombró como el hecho de que todos ocuparan el mismo punto, sin superposición y sin transparencia. Lo que vieron mis ojos fue simultáneo: lo que transcribiré sucesivo, porque el lenguaje lo es. Algo, sin embargo, recogeré (625).

En el cuento, a través de los dos hombres que llegan a contemplar el prodigioso fenómeno, se enfrentan dos concepciones del arte en cuanto al modo y a la actitud que puede adoptar el artista para posicionarse frente a la realidad: la del propio Borges y sus imágenes o "emblemas” místicos a (1984).

${ }^{1}$ Para simplificar, todas las citas de los textos de Borges provienen de Obras completas 
través de los cuales se busca una representación simbólica del infinito, por una parte, y, por otra, la de su oponente literario (y sentimental), Carlos Argentino Daneri. Éste, poeta también, opta por transmitir la percepción del Aleph a través de una segunda concepción posible, es decir, la del realismo fotográfico manifestado a través de su poema titulado "La Tierra”, el cual "tratábase de una descripción del planeta, en la que no faltaban, por cierto, la pintoresca digresión y el gallardo apóstrofe" (619).

Independientemente de la disputa estética en sí, nos parece que la problemática de fondo enunciada por el narrador, en cuanto a la complejidad que entraña la transmisión de una realidad infinita a través de un lenguaje que no lo es, es trasladable también a la dimensión de los mecanismos de representación social que la literatura utiliza. Concretamente, una posibilidad de observar el funcionamiento de esos dispositivos es el análisis que podemos efectuar a partir de la aparición de representaciones de grupos étnicos minoritarios en la obra de escritores. Esas representaciones, que suelen responder a la lógica del estereotipo, derivan en apreciaciones a través de las cuales se busca englobar las supuestas características distintivas de un colectivo (sea étnico o de cualquier otra clase), montando sobre el significado explícito de los enunciados una serie de implicaciones no siempre intencionales ni previstas conscientemente por el autor. Teun Van Dijk (2003) ha reflexionado sobre el asunto:

Debería hacerse hincapié desde un principio en que nuestra concepción de racismo también incluye el etnicismo, es decir, el sistema de predominio de un grupo étnico que se basa en la categorización mediante criterios culturales, la diferenciación y la exclusión, entre los que se encuentran el lenguaje, la religión, las costumbres o las concepciones del mundo. A menudo los criterios étnicos y raciales son inseparables dentro de estos sistemas de predominio, como es el caso del antisemitismo (2003: 24).

Entonces, el estereotipo que se selecciona para representar a un grupo étnico habilita a pensar en que su utilización puede considerarse como un proceso de confirmación de información preadquirida, ya que "cuando tenemos en mente imagen preestablecida que suscita una cierta expectativa, tendemos a seleccionar las informaciones nuevas que vienen a confirmar esa expectativa" (Amossy y Herschberg Pierrot, 2001: 53). 
Bajo esta concepción, en las páginas que siguen nos proponemos señalar algunos de los modos en que ciertas manifestaciones del pensamiento sustancialista-racista definido por Pierre Bourdieu², actúan en textos de un escritor cuyo desenvolvimiento en el campo literario, y particularmente durante el periodo histórico comprendido por los ejemplos que propondremos más adelante, no es, para utilizar etiquetas frecuentes, la de un "nacionalista", un "racista", "un antisemita", etc. Si bien sería posible emprender esta tarea analizando un abanico de temas diversos, en esta ocasión nos dedicaremos exclusivamente a uno en particular: el de los estereotipos del judío y de "lo judío" que aparecen en textos de Jorge Luis Borges y los observaremos apenas en algunos ejemplos representativos recogidos en las obras del escritor y que podemos relacionar a dos momentos históricos significativos: el final de la Segunda Guerra Mundial en 1945 y los sucesos de la Guerra de los Seis Días en 1967. Dichas fechas son arbitrarias, aunque su elección radica en dos motivos que justifican la decisión: el primero es la organicidad de las representaciones étnicas que pueden desprenderse de cada uno de los eventos, entendidos como sucesos históricos relevantes tanto desde el interior del grupo en cuestión como para la percepción externa del mismo. El segundo es la influencia, puesta de realce por el autor, de los eventos sobre la selección de temas y la escritura.

\section{El filosemitismo como bandera}

El caso de Borges y de sus representaciones acerca del mundo judío en sus ficciones es de interés a raíz de su doble posicionamiento en el campo literario tanto como un referente del ala liberal de la cultura argentina del siglo XX como de un confeso admirador de la cultura judía.

Definir lo que hemos denominado sector liberal en la órbita de la producción borgeana no resulta fácil, aunque la tarea de delimitación es esen-

\footnotetext{
${ }^{2}$ El sociólogo francés Pierre Bourdieu señaló que el sentido común responde a un tipo de pensamiento que él denomina "sustancialista", el cual "conduce a tratar las actividades o las preferencias propias de determinados individuos o determinados grupos de una sociedad determinada en un momento determinado como propiedades sustanciales, inscritas de una vez y para siempre en una especie de esencia biológica o -lo que tampoco mejoracultural" (1997: 15. Cursivas en el original).
} 
cial para comprender el sentido que damos a la propuesta de estudiar la naturalización del imaginario racista en el escritor. Como referencia para un primer acercamiento, y en cuanto a la elaboración de los discursos acerca del pasado como modo de autodefinición por parte de los diversos sectores del campo literario, resulta de interés la postulación de una auto-historia colectiva en los términos en que lo propone Hyden White al señalar que:

El pasado histórico es una construcción realizada seleccionando en el marco del amplio espectro de todos los eventos para los que pueden establecerse lugares y tiempos específicos de acaecimiento, y que pueden ser encuadrados en relatos diacrónicamente organizados de autoconstitución de un grupo a través del tiempo (2010: 124).

En ese sentido, es posible enfocar el liberalismo que enmarca a Borges como un colectivo que ha optado por algunos eventos particulares del siglo XIX, los ha interpretado de un modo determinado y los ha proyectado en el tiempo. Esa construcción de la auto-historia del grupo posibilita, por una parte, explicar el motivo por el cual los liberales del grupo Sur se consideraban herederos de los liberales antirrosistas del siglo XIX, y, por otra parte, permite enmarcar su autodefinición a partir de las posiciones asumidas primero frente al espectro nacionalista de la década de $1930 \mathrm{y}$, posteriormente, frente al peronismo, al que leyeron como un nuevo avance de la "barbarie" y la "tiranía" sobre la "civilización", representada por ellos mismos y por sus modos de entender la cultura. En ese eje es posible leer la asociación peronismo-antisemitismo frente a la de liberalismo-filosemitismo en el cuento "La fiesta del monstruo" escrito conjuntamente por Jorge Luis Borges y Bioy Casares ${ }^{3}$, en el cual se propone una nueva correlación para la serie introducida en 1837 por Esteban Echeverría en "El matadero": el caballero unitario es reemplazado en la ficción escrita por Borges y Bioy Casares por un "sinagoga”, es decir, un judío que representa los valores cul-

\footnotetext{
${ }^{3}$ Rodolfo Borello (1991) apunta que el relato "fue escrito en 1947 y circuló en copias mecanografiadas. Se publicó por primera vez en Marcha, Montevideo, 30 septiembre de 1955, más tarde fue reproducido por la sicalíptica (para la época...) revista Adán (Buenos Aires, ¿11961?) y traducido al inglés. 'Monsterfest', en Fiction, 5, 1, 1977, pp. 2-5” (178-9, nota 2). Para un análisis más detallado del texto, puede consultarse Orce de Roig (1999) y también Feinmann, 2008.
} 
turales frente al aluvional avance bárbaro (e innegablemente asociado con la ideología nazi) encarnado en los simpatizantes peronistas que lo lapidan.

Sin embargo, si bien esa lectura del campo es esencial para comprender la acción del grupo durante el decenio 1945-1955, pasa por alto la polarización que existía con anterioridad a la irrupción del peronismo en la vida política argentina. En esa línea, y a los efectos de precisar mejor los posicionamientos asumidos por el grupo, también resulta de utilidad la distinción planteada por John King en su libro sobre la revista Sur, donde se afirma que parte de la acción de esa publicación se centró en la definición, el autoposicionamiento y la defensa de un sector "liberal" a partir de una serie de pares antinómicos que se discuten en el campo artístico de la época:

El debate se centró en dos polos que pueden definirse, en términos generales, como liberal/populista, o universalista/nacionalista. Sur expresó una actitud liberal, universalista, y fue natural que sus adversarios se definieran en términos opuestos (...). En este mundo de dualidades sencillas, Sur fue condenada como "extranjerizante" (término despectivo, aplicado a los intelectuales cuyas ideas y actitudes fueron formadas por modelos extranjeros, en particular europeos), cosmopolita y elitista, en contraste con una cultura argentina "ideal", que debiera ser popular y nacionalista ${ }^{4}$ (1989: 16).

El sector nacionalista al cual se enfrentaron los liberales defendía, como parte de su dogma, rancias ideas de raigambre católica, que incluían una larga tradición antisemita ${ }^{5}$. Por razones de espacio no detallamos en pro-

\footnotetext{
${ }^{4}$ Para un testimonio en la misma dirección puede consultarse Croce, 1996. En página 15, por ejemplo, se califica a la revista Sur como "reducto del liberalismo". Véase, además, el apartado 2.2.2 donde se consideran las relaciones entre Sur y la izquierda.

${ }^{5}$ Gustavo Perednik ha intentado llamar la atención insistentemente acerca de la utilización errónea del término "antisemitismo" acuñado por Wilhem Marr en 1879 para referirse al odio en contra del judío. En su lugar, ha propuesto reemplazarlo por el término "judeofobia”, que fuera creado por León Pinsker poco tiempo después de que Marr propusiera el suyo. Entre los argumentos, Perednik señala la generalidad del término "semita" frente a la especificidad del fenómeno que busca denominarse, así como la inexistencia de un elemento racial en la manifestación del odio antijudío. Finalmente, opina que "El prefijo 'anti' combinado con el sufijo 'ismo' sugiere una opinión que viene a oponerse a otra opinión, como en las palabras antimercantilismo, antidarwinismo o antiliberalismo. Frente a esta imprecisión terminológica, concluye: "Pero la judeofobia no es una idea. JeanPaul Sartre, en su famoso libro sobre el tema, sugiere que no le permitamos al judeófobo disfrazar
} 
fundidad las características que se asocian con el estereotipo del judío difundido por escritores nacionalistas y del integrismo católico, como Hugo Wast. Suplimos parcialmente esa carencia, sin embargo, con la siguien-

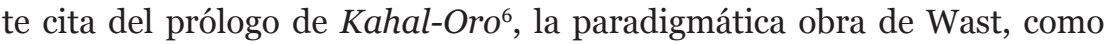
ejemplo concreto para comprender las posiciones adversas entre el sector nacional-católico y el liberal sobre este asunto:

Nadie ha perfeccionado tanto el sistema capitalista, como los banqueros judíos, Rothschild, etc.

Y nadie lo ha condenado con más acerbidad que los economistas judíos, Marx, etc.

El judío es conservador y es revolucionario. Conserva con tenacidad sus instituciones, pero tiende a destruir las de los otros.

Es patriota, como ningún otro pueblo, y al mismo tiempo fácil para abandonar la patria. Se le encuentra en todas partes, pero no es asimilado por ninguna.

Y la razón es simple: la patria real del judío moderno, no es la vieja Palestina; es todo el mundo, que un día u otro espera ver sometido al cetro de un rey de la sangre de David, que será el Anticristo (1935: 6).

Por lo tanto, a partir de lo expuesto hasta ahora, el problema reside en cómo poder detectar y describir el funcionamiento del discurso estereotipado acerca del judío en los textos de un autor cuya posición frente a dicho asunto no podría considerarse en línea con las manifestaciones abiertas, voluntaria y conscientemente discriminatorias lanzadas desde otros sectores del campo cultural. Para expresarlo con claridad, se busca demostrar en qué medida Borges contribuye a diseminar imágenes estereotípicas, aun

su odio de 'opinión'. En la medida en que usemos 'antisemitismo', los judeófobos podrán adornar a sus rencores con una aureola de criterio razonado, lo que además nos impide entender el fenómeno de la judeofobia con claridad" (2010: 3-4). Si bien los argumentos esgrimidos por Perednik son sólidos e inapelables desde un punto de vista dialéctico, en la práctica (y como el propio estudioso lo deja ver en sus trabajos) la difusión y penetración del término "antisemitismo" lo hace casi irreemplazable. En consecuencia, cuando en el transcurso de estas páginas, hagamos alusión al fenómeno del odio hacia el judío, estaremos partiendo del sustrato que propone Perednik, aunque utilicemos el impreciso término "antisemitismo" (o su antónimo, no menos impreciso, "filosemitismo").

${ }^{6}$ Se trata de un ensayo titulado "Buenos Aires, futura Babilonia" a través del cual el autor intentaba dar un sustento teórico a su novela. 
cuando en su discurso y en su posicionamiento ideológico explícito pueda manifestar (y de hecho lo hizo en numerosas oportunidades) lo opuesto.

\section{Emma Zunz y la Ley del Talión}

Desde el insistente recuerdo de que el hebraísta Rafael Cansinos Assens fue su querido maestro, Jorge Luis Borges siempre se manifestó como un admirador de la cultura judía y como un acérrimo defensor de la misma. Podría sostenerse que "lo judío", en general, cruza toda la producción literaria de Borges y que ha sido objeto de numerosos abordajes, aunque no desde la perspectiva que se propone en estas páginas. Es por ello que resulta especialmente significativo preguntarse las razones por las cuales el autor ha elegido, al momento de incluir personajes de origen judío, algunas representaciones estereotípicas tan alejadas de su propio pensamiento y sensibilidad al respecto.

En primer lugar consideraremos "Emma Sunz", cuento que forma parte de El Aleph, publicado en 1949. La peculiaridad de este cuento en relación con el resto de la obra del autor ha sido señalada en diversas ocasiones por la crítica. Uno de los puntos que más se ha destacado es el hecho de que Emma es, prácticamente, la única protagonista femenina en toda la narrativa de Borges. Por ejemplo, y para dar cuenta solamente de dos testimonios diversos al respecto, podemos traer a colación la opinión de Alicia Jurado quien insiste en que, en general, la mujer en la producción de Borges no tiene importancia alguna y que, en particular, "Emma Zunz" no debe ser tenido en cuenta para elaborar un juicio sobre este asunto ya que no es un argumento de Borges y que se trata de un personaje de características masculinas (1997: 126-7).

Por su parte, en uno de los análisis más originales del cuento, Edna Aizenberg ha defendido la posibilidad de una lectura cabalística en la que, a partir de la detección de ciertas asociaciones onomásticas, la autora concluye que "Emma Zunz" podría ser una reelaboración en clave del mito judío de la Shejiná7 (Jurado, 1997: 135 y ss). Aunque Aizenberg resalte con

A pesar de los posicionamientos tan distintos en torno de "Emma Zunz" que demuestran las dos estudiosas mencionadas, ambas apuntan en diferentes momentos de sus estudios a resaltar el pensamiento místico de Borges. En este sentido, Jurado define a Borges 
acierto que, en el sentido en que ella lo analiza, el cuento es prácticamente único dentro de la producción borgeana, es también necesario señalar la presencia de la imagen estereotipada del judío en el mismo.

En efecto, independientemente de otras posibilidades analíticas de valor, hay que resaltar que en el texto es posible advertir la aparición de estereotipos físicos y morales acerca del judío, con el agregado de que esos estereotipos podrían resultar funcionales a un pensamiento totalmente diverso al explicitado por Borges sobre el asunto. Es decir, la lectura simbólico-cabalística y la lectura más lineal (a menudo volcada a resaltar la simplicidad de la trama del relato), aunque resulten útiles para explicar algunos aspectos del cuento, no permiten dar cuenta de la complejidad y de la potencia que adquieren los estereotipos en el campo cultural.

Una primera confirmación de este juicio puede apreciarse en el argumento y en la descripción de los personajes. La acción del cuento gira en torno a la venganza que emprende una muchacha de origen judío, llamada Emma Zunz ${ }^{8}$, en contra Aarón Loewenthal, quien también es judío y es el patrón de la fábrica donde ella trabaja. Este último había acusado falsamente a Emmanuel Zunz, padre de Emma, y lo había obligado a exiliarse para huir de la justicia. Al comienzo de la narración Emma recibe la noticia sobre la muerte de su progenitor y es entonces cuando decide castigar a Loewenthal, quien es descripto por el narrador en los términos que siguen:

Aarón Loewenthal era, para todos, un hombre serio; para sus pocos íntimos, un avaro. Vivía en los altos de la fábrica, solo. Establecido en el desmantelado arrabal, temía a los ladrones; en el patio de la fábrica había un gran perro y en el cajón de su escritorio, nadie lo ignoraba, un revólver. Había llorado con decoro, el año anterior, la inesperada muerte de su mujer - iuna Gauss, que le trajo una buena dote!-, pero el dinero era su verdadera pasión. Con íntimo bochorno se sabía menos apto para ganarlo que para conservarlo. Era muy religioso; creía tener

del siguiente modo: "Una de las características de los pensadores místicos es la afición a expresarse por símbolos. Yo diría que la definición de Borges es la de uno de los grandes (y escasísimos) pensadores místicos de nuestra época" (1997: 98).

${ }^{8}$ A pesar de que Alicia Jurado resta importancia y valor a "Emma Zunz" en el marco general de la obra de Borges, la misma autora señala que el texto podría tomarse como ejemplo de uno de los temas preferidos por el escritor: es el motivo del destino (entendido como Dharma), que va asociado en muchas ocasiones con la muerte (Jurado, 1997: 105 y ss). 
con el Señor un pacto secreto, que lo eximía de obrar bien, a trueque de oraciones y devociones (566-7).

Las características estereotípicas del judío como un ser taimado, de doble moral, quien bajo una apariencia de mansedumbre, respetabilidad y honor, esconde una naturaleza de avaro y de eterna desconfianza, aparecen nítidamente en el fragmento citado. En efecto, en estas pocas líneas puede apreciarse cómo el personaje antepone el dinero y el lucro por sobre cualquier tipo de sentimiento (tal y como se aprecia en lo relativo a la dote y a la muerte de su esposa) o incluso cómo subordina la moralidad religiosa al beneficio material. El judío es un ser temeroso de los otros, a los que identifica con ladrones que siempre quieren robarle, es un apasionado del dinero que se interesa solamente por la acumulación especulativa e inmoral de riquezas. Esta apreciación es del todo coherente con la excusa utilizada por Emma para concretar la entrevista privada que le servirá de coartada para asesinarlo. Mientras en la fábrica hay "rumores de huelga", la protagonista se declara "como siempre, en contra de toda violencia" (565), pero posteriormente: “[Emma] llamó por teléfono a Loewenthal, insinuó que deseaba comunicar, sin que lo supieran las otras, algo sobre la huelga y prometió pasar por el escritorio, al oscurecer" (565). De esta manera queda expuesta la supuesta naturaleza intrigante del judío, tanto en el patrón que desea desactivar la incipiente huelga como en la obrera que traiciona a sus compañeros.

Como puede deducirse de lo anterior, la elaboración estereotípica es también apreciable en torno a la figura de Emma, la pretendida justiciera. La muchacha, que ha pasado gran parte de su vida alimentando un secreto odio en contra Loewenthal, ha hecho del rencor el eje de su existencia, hasta el punto de planear una venganza en la cual debe entregar su cuerpo y su virginidad a un anónimo marinero para luego poder simular un intento de violación por parte del patrón. En otras palabras, y en coincidencia con la figura de Simón del Rey, Emma encarna la supuesta impiedad del judío que nunca perdona y que nunca olvida las ofensas de que ha sido víctima, aspecto este que en el tradicional antisemitismo religioso lo diferencia del buen cristiano. En efecto, cuando Jesús pronunció El Sermón de la Montaña, propuso a sus discípulos olvidar la ley del Talión: "Oísteis que fue dicho: 'Ojo por ojo y diente por diente” (Mateo, 5: 38) y formuló 
en contraposición una imagen del cristiano siempre dispuesto a perdonar al prójimo, a colocar, como se dice, la otra mejilla: "No resistáis al que es malo; antes, a cualquiera que te hiera en la mejilla derecha, vuélvele también la otra" (Mateo, 5: 39). Emma, movida por el espíritu de la venganza, estaría aferrada a la antigua Ley o, más precisamente, a una interpretación espuria de la misma que le sirve para justificar sus odios personales antes que para alcanzar una justicia verdadera. En el origen de su plan, Emma se considera un instrumento de justicia:

ella se había soñado muchas veces, dirigiendo el firme revólver, forzando al miserable a confesar la miserable culpa y exponiendo la intrépida estratagema que permitiría a la Justicia de Dios triunfar de la justicia humana. (No por temor, sino por ser un instrumento de la Justicia, ella no quería ser castigada) (567).

El fracaso de su empresa se puede anticipar cuando el narrador comenta que al estar frente a Loewenthal, "más que la urgencia de vengar a su padre, Emma sintió la de castigar el ultraje padecido por ello" (567), es decir antepone a la memoria de su padre el desagrado que siente por haber consentido la relación sexual con el marinero. Pero el fracaso de la empresa se corrobora brutalmente a través de las palabras del narrador cuando, luego de ultimar al hombre, se informa que: "Emma inició la acusación que tenía preparada ("He vengado a mi padre y no me podrán castigar...”), pero no la acabó, porque el señor Loewenthal ya había muerto. No supo nunca ni alcanzó a comprender" (567). En este sentido, podría aseverarse que la justiciera, al verse impedida de comunicar la sentencia que condena a muerte al acusado, deviene en una simple asesina cuyos motivos son desconocidos por la víctima.

Como es fácil notar, tanto el personaje de Loewenthal como el de Emma, responden total o parcialmente a prejuicios arraigados desde tiempos antiguos en el mundo occidental acerca de la naturaleza moral del judaísmo. Esos núcleos participan de la cultura de un modo relativamente independiente, lo cual permite explicar por qué un escritor como Borges, que no adhería a las ideologías que enarbolan abiertamente los estereotipos sobre lo judío para justificar sus posiciones ideológicas y acciones concretas, puede utilizar los mismos sin percibir en ese acto una contradicción. 


\section{La Guerra de los Seis Días}

Finalmente nos parece pertinente insistir, como ya fuera remarcado, en que los estereotipos estudiados hasta aquí son fácilmente reconocibles. Pero la tarea se vuelve más compleja cuando no existe un trabajo a partir de la mirada negativa sobre la cual se asienta el estereotipo, sino cuando se pretende exaltar a la minoría en cuestión. Esta utilización, en relación con la mirada estereotipada del judío y del judaísmo, es la más representativa de la obra borgeana. Para dar solamente un ejemplo, podríamos considerar el poema titulado "Israel" que Borges escribiera con motivo de la Guerra de los Seis Días en 1967 y que forma parte de Elogio de la sombra de $1969^{9}$.

En ese texto, Borges se propone celebrar la figura del judío aunándola a la victoria militar obtenida. El poema, de marcado tono exaltatorio, comienza por enumerar algunos de los estereotipos más utilizados a lo largo del tiempo como pretexto para castigar al pueblo hebreo. Los versos iniciales del poema dicen así:
Un hombre encarcelado y hechizado, un hombre condenado a ser la serpiente que guarda un oro infame, un hombre condenado a ser Shylock (997).

Según señala Edna Aizenberg en el estudio ya citado: "esta imagen estereotipada del judío usurero, probablemente más asentada en la cultura occidental que la del judío intelectual, es conocida por Borges, pero le interesa poco" (1997: 109). Si bien, como hemos visto, este conjunto de imágenes estereotipadas sí puede apreciarse con nitidez en Emma Zunz, aquí funciona como un elemento de contraste, que marca distancia con otro cuerpo de estereotipos que, aunque de carácter positivo, resultan igualmente simplificadores y deformantes. Aizenberg habla de una "fascinación de Borges por el judío como intelectual” (109), que se aprecia, justamente, en el mismo poema:

\footnotetext{
${ }^{9}$ En Elogio de la sombra hay tres composiciones dedicadas a Israel: “A Israel”, "Israel” e "Israel, 1969", lo cual da buena idea de la importancia que el tema tenía para el autor en aquel momento y también de la impresión que causaron en su ánimo tanto la Guerra de los Seis Días (1967) como su visita al país (1969).
} 
un hombre que a pesar de los hombres es Spinoza y el Baal Shem y los cabalistas, un hombre que es el Libro, una boca que alaba desde el abismo la justicia del firmamento, un procurador o un dentista que dialogó con Dios en una montaña (997).

Estos versos contienen muchas de las claves esenciales a través de las cuales Borges entiende al judaísmo: algunos autores admirados, la elaboración de sistemas filosóficos complejos, el amor por los libros, la lectura y la interpretación, entre otros núcleos. A pesar del notorio sentido positivo con que el escritor consigna estos elementos, no puede perderse de vista el alto grado de estereotipicidad que encierran. Aunque no sean utilizados con una voluntad estigmatizante, queda demostrado que estos estereotipos también reflejan ideas sustancialistas acerca de la minoría señalada. Para completar esta percepción debería tenerse en cuenta el valor que se da, tanto en la composición considerada aquí como en las otras dos que se refieren a Israel incluidas en el mismo libro, a lo que Borges considera como una guerra legítima del pueblo judío por su subsistencia, tal y como se desprende de los versos finales del poema:
un hombre que se obstina en ser inmortal y que ahora ha vuelto a su batalla, a la violenta luz de la victoria, hermoso como un león al mediodía (997).

Al parecer, en la perspectiva borgeana, uno de los caminos para superar la estigmatización es la "vuelta a la batalla", es decir que la violencia que condenaba a Emma salva al pueblo del, por entonces naciente, Estado de Israel. Estas ideas de revancha y de liberación a través de la lucha se vinculan con el llamado "Mito del Judío Errante"10, considerada como una de las imágenes más estigmatizantes sobre el judío y sobre el judaísmo.

${ }^{10}$ La Enciclopedia de la Historia y la Cultura del pueblo judío señala en su entrada sobre este personaje que se trata de una "figura legendaria que simboliza, según algunas tradiciones cristianas, el destino del pueblo judío después de la muerte de Jesús" (Zadoff, 1998: 217). La misma fuente asegura que la leyenda se originó en Constantinopla, en el 
La extensa difusión y pluralidad de significados del Judío Errante no permiten un abordaje completo en estas líneas, aunque sí resulta preciso reflejar su rol en la percepción del judío como un ser malvado y terco que no quiso reconocer al Hijo de Dios y, posteriormente, como un ente ajeno al cuerpo Nacional e incluso como un peligro para su subsistencia. Estos rasgos pueden asociarse, por una parte, con la eterna vagancia a la que fue condenado Asuero, el zapatero sobre el cual Jesús lanzó su maldición, y su consecuente desarraigo (que explicaría la diáspora judía como un castigo) y, por otra parte, con la maldad del personaje que no permitió el descanso de Jesús (que funciona como una advertencia acerca de la perversidad intrínseca de los miembros de esa etnia). Ariana Huberman y Alejandro Meter (2006) recuerdan en la introducción a la colección de ensayos Memoria y representación: configuraciones culturales y literarias en el imaginario judío latinoamericano que:

Una de las conexiones más fuertes entre judeidad y otredad en la percepción popular tiene su origen en el mito del judío errante. Este mito cristiano se refiere al judío como el máximo exponente del extranjero (...). En la mayoría de los casos, el castigo de errancia perpetua se recibe por haber ofendido a una deidad a través de un acto de arrogancia. La versión más común en la mitología cristiana trata sobre un zapatero de Jerusalén que no le permitió a Cristo que se sentara frente a su puesto. Por lo tanto Jesús castigó al zapatero haciéndole caminar por la tierra hasta su retorno el día del juicio final (2006: 13).

siglo IV, y que fue difundida por Europa mediante un libro del monje Matthew Paris en el siglo XIII. La enciclopedia explica, además, que "la imagen del judío errante penetró profundamente en la conciencia de los pueblos cristianos y sirvió de justificación al antagonismo religioso, a persecuciones y al antisemitismo, y encontró vías de expresión en cientos de obras de diverso género" (218). La fundación del Estado de Israel, con su ideal de base de "retorno a la patria" y del final de la diáspora que llevó aparejada, supuso un duro golpe en contra del mito. Martin Gardner vincula esta leyenda con la necesidad de los predicadores cristianos de encontrar alguna explicación al retraso de la profecía según la cual la Segunda Venida de Cristo a la tierra ocurriría antes de que murieran todos los testigos de sus hechos (2009: 303-305). Si bien el judío errante se vincula con la línea del antisemitismo religioso, ya que representa la supuesta falta de piedad de los judíos que no aceptaron el mensaje de amor difundido por Jesús y su consecuente castigo colectivo a través de la diáspora (recreado en la eterna vagancia de Asuero o Hahashverosh), también fue utilizado por los ideólogos y propagandistas nazis para justificar, por ejemplo, la "Solución final del problema judío”, como denominaron el plan para el genocidio a partir de la Conferencia de Wannsee de 1942. 
Daniel Lvovich (2003) indaga acerca de cuáles podrían ser las causas de la aparición en la literatura argentina de un antisemitismo tan virulento como el que se observa en la novela de Julián Martel y asigna en ese panorama un rol central a la leyenda en cuestión. De esa manera el estudioso, siguiendo a David Viñas, arriesga la hipótesis de que el malestar expresado en contra del judío a finales del siglo XIX está vinculado a su permanente extranjerización:

Viñas ha sostenido que Martel no hizo más que exacerbar el malestar de los "antiguos señores" frente a los inmigrantes, centrando su acusación en los judíos -a los que probablemente no conocieran- pero que idealmente eran los extranjeros por antonomasia. En efecto, el carácter de pueblo sin territorio, el estereotipo universal acerca del 'judío errante', la marcada singularidad cultural de los israelitas y su origen no latino que contrastaba con el de la mayoría de los inmigrantes, sumado a la tradicional perspectiva cristiana sobre los judíos, tornan muy verosímiles las hipótesis de Viñas acerca del carácter de extranjeros por antonomasia de los judíos para el pensamiento finisecular (2003: 60).

Por lo tanto, a través de la exaltación de la victoria militar obtenida por Israel, es evidente que Borges celebra el final de la diáspora y, en consecuencia, la cancelación definitiva de uno de los núcleos estigmatizantes más férreos en torno a la figura del judío ${ }^{11}$.

\section{La amenaza inesperada: Conclusiones}

El caso de Borges, a través de los ejemplos analizados, permite observar dos cuestiones de interés. La primera, que permite vislumbrar una posible

${ }^{11}$ En contraste con ello, y para dar la pauta de que algunos escritores todavía se nutrían del sustrato mítico antisemita en un sentido bastante literal, podríamos señalar que Manuel Mujica Lainez, asociado también al círculo liberal, aunque con un pasado militante en los círculos del integrismo católico, recurre al Judío Errante en tres textos: en el cuento "El vagamundo", incluido en Misteriosa Buenos Aires (2001), el judío errante es el protagonista de la historia, mientras que en las novelas El Unicornio (1979 [1965]) y El laberinto (1989 [1974]) aparece de modo circunstancial aunque significativo. Es evidente que la utilización que hace Mujica Lainez responde a la concepción del mito original, recogida quizás durante su paso por los núcleos nacionalistas argentinos durante la década de 1930, que siguió gravitando sobre su escritura aun cuando el escritor se distanció de esos sectores al comenzar la Segunda Guerra Mundial. 
base analítica para la teoría de los estereotipos, es que el mecanismo de reemplazar un cuerpo de imágenes estereotipadas marcadamente negativo que hemos analizado en "Emma Zunz" por otro cuerpo de orden positivo, que se aprecia en los poemas de Elogio de la sombra, no soluciona el problema del pensamiento sustancialista que las anima. Dejando de lado las intenciones perseguidas, incluso si pudiera darse por sentado que esas intenciones son conscientes, la presencia de estereotipos "positivos" en la producción de un autor no difiere en nada de la percepción de estereotipos "negativos". En otras palabras, la identificación de imágenes estereotipadas de lo judío no remite aquí a una dinámica antinómica de lo bueno y de lo malo, sino a la presentación de imágenes deformantes de un grupo y de una cultura determinados. Imaginar como benéficos intelectuales a todos los individuos judíos es un acto de falseamiento tanto como podría ser la caracterización de los mismos como seres ambiciosos, impiadosos y vengativos, por ejemplo.

La segunda, las manipulaciones críticas para polarizar la mirada acerca del asunto, también remiten a la dinámica del pensamiento sustancialista. El hecho evidente de un Borges comprometido en la defensa de los judíos, a la sazón perseguidos por el nazismo, por ejemplo, hace necesario intensificar la presentación del autor como un filosemita y, consecuentemente, negar cualquier rasgo de su literatura que pudiera arrojar una mínima sombra de sospecha que hiciera parecer lo contrario. Sin embargo, como ya se dijo antes, no se trata de acusar a Borges de ser antisemita, sino de observar cómo ha recurrido al sustrato estereotípico existente y de preguntarse los motivos por los cuales se ha inclinado a su utilización.

En cierta medida, si el uso de las imágenes estereotipadas por parte de los autores es inevitable, como lo señala el estudio de Amossy y Herschberg Pierrot, los críticos están también sometidos a esa ley. Lo que debería considerarse en este caso es qué motivo subyace en las elecciones que se realizan a la hora de analizar los textos de un autor y por qué muchos críticos intentan negar de plano lo que es evidente: que los estereotipos aparecen en las obras y que su cercanía al pensamiento sustancialista, como una consecuencia colateral, es innegable. Es posible que se llegue a la conclusión de que estas operaciones de los críticos responden, a su vez, a un pensamiento francamente estereotipado, el sentido común que impera en el campo cultural y que dicta los modos en que un escritor debe ser abordado. 
Probablemente la respuesta o, mejor dicho, una posible respuesta se halle inscripta en la obra del propio Borges. Como lo señala Carlos Fuentes, en un ensayo que coincide manifiestamente con las ideas a las cuales hicimos referencia al iniciar este trabajo:

Borges nos enseñó a comprender, en primer lugar, la realidad relativista aunque incluyente del tiempo y el espacio modernos. No puede haber sistemas de conocimiento cerrados y autosuficientes, porque cada observador describirá cualquier acontecimiento desde una perspectiva diferente. Para hacerlo, el observador necesita hacer uso de un lenguaje. Por ello, el tiempo y el espacio son elementos de lenguaje necesarios para que el observador describa su entorno (2013: 152).

El problema no tiene una solución, sino que tiene múltiples enfoques. Debemos insistir en que si bien la utilización de los estereotipos es inherente a las actividades humanas, en tanto que es un modo económico de redistribuir la información y de apelar a un sustrato compartido entre el emisor y el receptor, ese hecho no supone que deba pasarse por alto la aparición de personajes estereotipados en la obra de un escritor. En efecto, si como señala Zaffaroni (2010) los estereotipos "son simientes de masacre esparcidas al azar" que facilitan "el camino de la agresión y hasta del crimen", la tarea de señalarlos es fundamental para comprender su funcionamiento y el origen del pensamiento sustancialista. Mucho más si ese pensamiento está inscripto en la obra de un autor que, como se dijo en varias ocasiones, no se identifica abiertamente con el sector del campo cultural que esgrime abiertamente el ideario etnicista.

\section{Referencias}

Amossy, R. y Herschberg Pierrot, A. (2001). Estereotipos y clichés. Buenos Aires: Eudeba.

Borello, R. (1991). El peronismo (1943-1955) en la narrativa argentina. Ottawa: Dovehouse Editions Canada.

Borges, J. L. (1984). Obras completas: 1923-1972. Buenos Aires: Emecé editores. Bourdieu, P. (1997). Razones prácticas: sobre la teoría de la acción. Barcelona: Anagrama.

Croce, M. (1996). Contorno: izquierda y proyecto cultural. Buenos Aires: Colihue. 
Feinmann, J. P. (2008). Borges y La Libertadora. En Peronismo: Filosofía política de una obstinación argentina - Fascículo $\mathrm{N}^{\circ} 27$, suplemento especial de Página12, 25 de mayo. Disponible en http://www.pagina12.com.ar/especiales/archivo/peronismo_feinmann/CLASE27.pdf

Fuentes, C. (2013). La gran novela latinoamericana. Buenos Aires: Alfaguara. Gardner, M. (2009). El Judío Errante y la Segunda Venida. En Ch. Hitchens, Dios no existe: lecturas esenciales para el no creyente (pp. 301-309). Madrid: Debate.

Huberman, A. y Meter, A. (eds.) (2006). Memoria y representación: configuraciones culturales y literarias en el imaginario judío latinoamericano. Rosario: Beatriz Viterbo Editora.

Jurado, A. (1997). Genio y figura de Jorge Luis Borges. Buenos Aires: Eudeba. King, J. (1989). Sur. Estudio de la revista argentina y de su papel en el desarrollo de una cultura (1931-1970). México: Fondo de Cultura Económica.

Lvovich, D. (2003). Nacionalismo y antisemitismo en la Argentina. Buenos Aires: Javier Vergara Editor.

Mujica Lainez, M. (1979 [1965]). El Unicornio. Buenos Aires: Sudamericana. . (1989 [1974]). El laberinto. Buenos Aires: Sudamericana. . (2001). Misteriosa Buenos Aires. Madrid: Planeta.

Orce de Roig, M. E. (1999). 'La fiesta del monstruo' de 'Biorges': un texto diferente. Revista de literaturas Modernas, 29, 233-248.

Perednik, G. D. (2010). La naturaleza de la judeofobia. Buenos Aires: Clam. Van Dijk, T. A. (2003). Racismo y discurso de las elites. Barcelona: Gedisa.

Wast, H. (1935). Buenos Aires, futura Babilonia. Prólogo. En Kahal-Oro (pp. 2-19). Buenos Aires: Editores de Hugo Wast.

White, H. (2010). Ficción histórica, historia ficcional y realidad histórica. Buenos Aires: Prometeo Libros.

Zadoff, E. (dir.) (1998). Enciclopedia de la Historia y la Cultura del pueblo judío. Jerusalén: E.D.Z. Nativ Ediciones.

Zaffaroni, E. R. (2010). Prólogo. En M. Braylan (comp.), Exclusión e inclusión. El problema de los colectivos discriminados (2008-2009) (pp. 7-9). Buenos Aires: CES. 